\title{
Jan Patočka's Concept of Fraternity and its Challenges vis-à-vis the World of Today
}

\section{Zuzana Svobodová}

\section{Envigogika 12 (2) - Reviewed articles / Recenzované články}

Published / Publikováno 28. 12. 2017

\author{
DOI: $10.14712 / 18023061.556$
}

\begin{abstract}
The presentation entitled "Jan Patočka's Concept of Fraternity and its Challenges vis-à-vis the World of Today" discusses the concept of fraternity explored by the Czech philosopher in his later texts. Patočka was one of the authors of Charter 77, a dissident document, which called for the protection of human rights (published on January 6.-7., 1977). At the outset, Patočka's theory of three movements of life (also: movements of the soul) - i.e. the movement of rooting or anchoring, the movement of labour or self-delivery and the movement of breakthrough or finding oneself - will be analysed. Based on the analysis, the role of turning (gr. metanoiésis) from a mere solidarity of interests to self-realisation through self-surrender will be shown. Jan Patočka interpreted life as surrender by referring to the notion of the God-man and the way the world relates to him. The phenomenon of sacrifice that Jan Patočka dealt with in the last period of his life (Patočka died on March 13, 1977, following long and exhausting police interrogations) is inspirational for the field of social ethics, both from philosophical and theological points of view. It also comes with challenges to education and training in today's Europe, which faces migration, requiring us to learn new habits of hospitality and fraternity.
\end{abstract}

\section{Keywords}

Jan Patočka; Charter 77; fraternity; movements of life; conversion; kairos.

\section{Abstrakt}

Článek „Pojetí bratrství u Jana Patočky" pojednává o konceptu bratrství v textech, které český filozof napsal $v$ pozdějších fázích svého života. Jan Patočka byl jedním z autorů Charty 77, disidentského dokumentu, který vyzval k ochraně lidských práv (publikováno 6.-7. ledna 1977). V tomto textu autorka za prvé analyzuje Patočkovu teorii třech životních pohybů (nebo také pohybů duše), které představují pohyb zakořenění nebo ukotvení, pohyb práce nebo sebezbavení a pohyb průlomu či sebenalezení. Na základě analýzy se ukazuje význam obratu (metanoiésis), od pouhého zájmu a solidarity až ke skutečnému bytí $v$ odevzdanosti. Jan Patočka interpretoval život $v$ odevzdanosti pomocí pojmu bohočlověka a způsobu, jakým se k němu svět vztahuje. Fenomén oběti, jímž se Jan Patočka zabýval v posledním období svého života (Patočka zemřel 13. března 1977, po dlouhých a vyčerpávajících policejních výsleších), může být inspirací pro myšlení sociální etiky, a to jak z filozofického, tak i z teologického hlediska. To pak může pomoci čelit výzvám pro vzdělávání a odbornou př́pravu v dnešní Evropě, která se potýká s migrací, nebot' se její obyvatelé musí naučit nově praktikovat svou pohostinnost a bratrství.

\section{Klíčová slova}

Jan Patočka; Charta 77; bratrství; životní pohyb; konverze; kairos 
Forty years ago, on March 1, 1977, based on the initiative of foreign journalists, the then Dutch foreign minister Max van der Stoel met with the Czech philosopher Jan Patočka in the Prague Intercontinental hotel and made it possible for him to speak at a press conference to an audience of foreign journalists about the Charter 77 document. After the meeting, Jan Patočka was interrogated harshly by the Czechoslovak secret police for several days and he died of an apoplectic stroke on the morning of March 13, 1977.

Jan Patočka dealt with the notion of fraternity in his work Kaciřské eseje o filosofii dějin (English: Heretical Essays on the Philosophy of History), specifically in the third part, entitled Does History Make Sense?). ${ }^{1}$ In the context of Patočka mentioning a new community, a new city, which "is no longer entirely the work of men", but in which people participate freely in a community not only comprised of people, but instead a "community with God". ${ }^{2}$

Patočka deals with the topic of a new quality of the community also in texts, where he discusses the notion of breakthrough: breaking through the alienation from oneself, the others and the world ${ }^{3}$, the alienation that occurs in the second life movement, the second movement of the soul, through work, competition, fulfilling one's basic needs, functioning or otherwise and losing oneself in this movement by self-exertion. Patočka deals with three movements of life: the movement of rooting (anchoring), work, and finding oneself.

The breakthrough itself conditions a change in how human existence is understood: now, one's own being is seen not "as being for myself", but as "being through surrender", existence which opens itself to being; living so as to enable things to be revealed for what they are - similarly being true to oneself and to others. Thus, what is meant here is a breakthrough towards a life of abandonment, where the emphasis is not put on a mere solidarity of interests, but on a complete turnaround "of interests - no longer does one live in what causes separation and closures, but what leads to unity and openness because this is openness per $\mathrm{se}^{\prime \prime}{ }^{4}$

Life is surrendered in this conversion, the rising up from the second movement, this : "metanoia": "Thus, it overarches the community of those who find understanding among themselves in this surrendering and abandonment, and who - by denying discrete centres - create the same unified community of surrender, community in committed service, which transcends the individual". ${ }^{5}$ Patočka also seeks to clarify that in this rise, people are not only connected among themselves, but they create a community of service which is related to the world. In this way the most substantial relationship of a human being to the world is created, the important relationship between man, the world and essence. ${ }^{6}$ Patočka considers this movement to be the most important ${ }^{7}$, because to him it is a movement, when the truth, the word becomes flesh, when the event of being is fully manifested in people. One who is able to live fully, completely or utterly in surrender, rightly deserves to be called God-man. This movement of a breakthrough from alienation is an aggrandizement, an upward swing.

\footnotetext{
${ }^{1}$ See Patočka 2002: 81. - 584: "Wo infolgedessen eine Brüderlichkeit der in der Naivität Erschütterten, ihre Solidarität über Konflikte und Widersprüche hinaus, nicht nur möglich ist, sondern notwendig gefordert wird?"

2 Patočka 2002: 74.

${ }^{3}$ See Patočka 2006 B: 408.

${ }^{4}$ Patočka 2009: 332-333.

${ }^{5}$ Patočka 2009: 365-366.

${ }^{6}$ See Patočka 2009: 366.

${ }^{7}$ See Patočka 2009: 361, 366.
} 
At the same time, it keeps the first movement of acceptance and the second movement of labour "in suspension as a mere potential, not the full reality of human existence". ${ }^{8}$

In the third movement, that of existence, "we understand that final existence may not and must not close itself in the way material being closes itself, since existence is openness in its whole essence [...] [We understand] that, in its essence, it is being, which is sacrificed, because it is final, and, therefore, this is what it should choose to do". ${ }^{9}$ Patočka then closes with the following reference: If one is to live in truth and freedom, if he/she is to live as one who controls rationality and is not controlled by it, "then, I think, we have to understand that any truth lies in the awakening of existence, in the realization of its fundamental openness". ${ }^{10}$

That which makes these movements of human existence possible has been called since the ancient era of philosophy, psyché or the soul. The principle of movement, the principle of life is referred to as psyché.

Plato attempted to portray the whole community as soul. Patočka, who dealt with the analysis and interpretation of these ancient texts, points out to the eighth book of The Republic, where Plato explained what happens in the transition from being to possessiveness. This transition also belongs to the principle of community, and it seizes the souls of citizens, causing them to be subdued to things and lust: "When the soul gives in to this movement, when it exchanges its being for possessiveness, for example for superficiality, for changeable things, then peace will not occur until extreme [spiritual] poverty, errantry and blindness are reached. Such misfortune of the community and its individuals is something that everyone can feel, but only the philosopher knows the reasons for why this is the case. The philosopher accuses neither god, nor fate; because he knows about the essence of the soul as self-movement within the meaning of self-determination, thus he knows and sees who is truly guilty". ${ }^{11}$ Only those who dedicated themselves to possessiveness, isolation, competition, not to openness, service, and dedication are guilty. Such extreme poverty of the soul, errantry and blindness often lead to awareness of loneliness, living without relationships, without fraternity. Only re-establishing relationships with others, giving oneself away in selflessness - to people, sense, and the truth - which means living in openness, through sacrifice, only that can actually return an individual to the living community, to fraternity.

At the same time, however, the following is made clear: man is unable to achieve this aggrandizement on his own, from within their closed attitude, from their possessiveness. In order for a human being to live in a relationship, they must be open, not closed. "This, however, can be achieved by no individual, this can only be achieved in the community"12, for example when a person lives "to the benefit of the whole". ${ }^{13}$

Patočka noted Aristotle's response to Plato's concept of the soul (which, to Patočka, is in line with the concept of movement): Aristotle noticed that Plato's interpretation of movement does not distinguish "escalation of being in actuality". ${ }^{14}$ In Plato's terms, the soul

\footnotetext{
${ }^{8}$ Patočka 2009: 361.

${ }^{9}$ Patočka 2006: 408.

${ }^{10}$ Patočka 2006: 408.

11 Patočka 1999: 382.

12 Patočka 1999: 382.

${ }_{13}^{13}$ Patočka 1999: 382.

${ }^{14}$ Patočka 1999: 380.
} 
moves in a kind of realm beyond the confines of time. Yet it is only Aristotle who introduces a new doctrine of being, the axis of which is the difference between dynamis (being in potentiality) and energeia (being at work, real, realising being). ${ }^{15}$

Today, energy is understood primarily as a current, proliferation. Being en-ergó means to exist, step out of isolation to what is essential, for example in the very current of m/Meaning.

Forty years ago, Professor Jan Patočka, one of the three initial spokesmen of Charter 77 (another being Václav Havel), wrote: "The Charter was only intended to function pedagogically. But what does it mean to act pedagogically? We can only be educated by ourselves, often inspired by someone else's example; one can also be scared off by poor results and advised by dialogue and discussion. Education means to understand that there is more to life than fear and benefit... The Charter wishes... [t]o make people aware that in the world it is not money or power, nor talent, what is crucial; the most important thing is to be in the right place at the right time". ${ }^{16}$ From Jan Patočka's correspondence it is clear that unlike some colleagues around Charter 77 he himself was aware of the seriousness of that time, of the "Kairos" time, and because he was aware of the seriousness of the moment, he did what was necessary for the sake of fraternity. For this act of substantial opening Jan Patočka lost his life, but he made this sacrifice readily.

And so, not only through Patočka's words but also through his act, those who are not blind to the truth of the closing down rather than opening up of humanity, are shaken and awakened to humanely face this challenge. Thus, fraternity can emerge, which Jan Patočka mentioned in the German version of his Heretical Essays: inevitably necessary fraternity and solidarity of those who had been shaken and awakened from their naiveté, from being totally absorbed by their basic needs, from always being busy - from aschólia. It is an important fraternity of those who seek to live in truth, for the life of the spirit. ${ }^{17}$

\section{Bibliography:}

- Patočka 2006 A: PATOČKA, Jan. Češi I: soubor textů k českému myšlení a českým dějinám: práce publikované. Oikoumenē: Filosofia, 2006. ISBN 80-7298-181-1.

- Patočka 2006 B: PATOČKA, Jan. Češi II: soubor textů k českému myšlení a českým dějinám: práce nepublikované. Oikoumenē: Filosofia, 2006. ISBN 978-807-2981823.

- Patočka 2009: PATOČKA, Jan. Fenomenologické spisy II. Praha: OIKOYMENH, 2009, 669 s. Sebrané spisy Jana Patočky: Svazek 7. ISBN 978-80-7298-420-6.

- Patočka 2002: PATOČKA, Jan. Péče o duši III. Praha: OIKOYMENH, 2002. Sebrané spisy Jana Patočky: Svazek 3. ISBN 80-7298-054-8.

\footnotetext{
${ }^{15}$ See Patočka 1999: 381.

16 Patočka 2006 A: 443-444.

17 See Patočka 2002: 81.
} 